\title{
Profitabilitas sebagai Pemoderasi Nilai Saham Perusahaan Industri Barang Konsumsi
}

\author{
Widya Sari ${ }^{1}$ \\ Fakultas Ekonomi \\ Universitas Prima Indonesia, Indonesia Universitas Prima Indonesia, Indonesia \\ Email: widyasari@unprimdn.ac.id
}

\author{
Fiona Audrey 3 \\ Fakultas Ekonomi \\ Universitas Prima Indonesia, Indonesia
}

\begin{abstract}
ABSTRAK
Penelitian ini bertujuan untuk mengetahui dan menganalisis bagaimana pengaruh Current Ratio, Inventory Turnover, Fixed Asset Turnover dan Debt to Equity Ratio terhadap Nilai Saham dan profitabilitas sebagai variabel moderasi pada perusahaan consumer goods yang tercatat di Bursa Efek Indonesia (BEI). Populasi yang digunakan dalam penelitian ini berjumlah 39 perusahaan dan sampel yang digunakan sebanyak 14 perusahaan. Dari penelitian didapatkan hasil bahwa Fixed Asset Ratio dan Debt to Equity Ratiomemiliki pengaruh terhadap nilai saham. Dengan menggunakan profitabilitas sebagai pemoderasi maka Current Ratio dan Debtto Equity Ratio berpengaruh terhadap nilai saham.
\end{abstract}

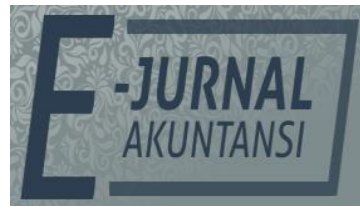

Kata Kunci: Current Ratio (CR); Inventory Turnover (ITO); Fixed Asset Turnover (FAT); Debt to Equity Ratio (DER); Harga Saham.

\section{Profitability as Moderator Variable to Companies Stock Price in Consumer Goods Industry}

\section{ABSTRACT}

This study aims to determine and analyze how the influence of Current Ratio, Inventory Turnover, Fixed Asset Turnover and Debt to Equity Ratio on Stock Price and Profitability as a moderating variable to consumer goods sector companies listed on the Indonesia Stock Exchange (IDX). Population in this study are 39 companies and 14 companies used as samples. This research uses purposive sampling method. The results of this study indicate that the Fixed Asset Ratio and Debt to Equity Ratio affects stock value. By using profitability as a moderator, Current Ratio and Debt to Equity Ratio affects the value of the stock.

Keywords: $\quad$ Current Ratio (CR); Inventory Turnover (ITO); Fixed Asset Turnover (FAT); Debt to Equity Ratio (DER); Stock Price. 


\section{PENDAHULUAN}

Kinerja pendapatan emiten barang konsumsi (consumer goods) pada awal tahun 2019 relatif meningkat. Dari sisi eksternal, faktor pendorong sektor ini berupa stabilitas rupiah dan harga komoditas global (Arief, n.d.). Hasil riset yang dilakukan oleh Danareksa Research Institute (DRI) menunjukkan Indeks Keyakinan Konsumen (IKK) pada Januari 2020 turun 2,3 persen menadi 102,5. Padahal pada bulan Desember 2019 lalu, angka survei IKK masih di level 104,9. Vice President Research Artha Sekuritas Indonesia, Frederik Rasali menilai, emiten sektor consumer goods memiliki prospek cerah sepanjang tahun ini (Suryahadi, n.d.). Pencapaian kinerja keuangan perusahaan dinilai dari nilai rasio keuangan yang dihasilkan.

Current Ratio (CR) merupakan rasio likuiditas, apabila rasio likuiditas terlihat baik dan kondisi ini berjalan secara stabil maka rasio nilai pasar juga akan tinggi dan hal tersebut akan mempengaruhi harga saham (Gultom, Purba, Zepria, \& Sinaga, 2019). Fixed Asset Turnover (FAT) merupakan rasio yang melihat bagaimana perputaran aset tetap suatu perusahaan dalam menghasilkan penjualan. Angka rasio aktivitas perusahaan yang tinggi menunjukakan pemanfaatan aktiva yang baik oleh perusahaan tersebut (Warrad \& Al Omari, 2015). Perputaran persediaan atau Inventory Turnover (ITO) digunakan untuk mempelajari kemampuan perusahaan dalam pengelolaan persediaannya. Semakin tingginya angka rasio ini, maka semakin cepat persediaan diubah menjadi penjualan (Hoiriya \& Lestariningsih, 2015). Debt to Equity Ratio (DER) mencerminkan tingkat resiko suatu perusahaan, para investor akan mempertimbangkan tingkat resiko yang dimiliki oleh suatu perusahaan. Angka $D E R$ yang tinggi mencerminkan tingkat resiko yang tinggi namun investor akan tertarik berinvestasi pada perusahaan jika nilai DER tidak melebihi batas hutang dan tidak lebih besar dari modal perusahaan (Rahmawati \& Suryono, 2017).

Return On Asset digunakan untuk mengukur keuntungan bersih yang diperoleh dari penggunaan aktiva. Semakin tinggi rasio ini maka produktivitas akan semakin baik, hal ini akan meningkatkan daya tarik perusahaan di mata investor. Hal ini akan berpengaruh terhadap harga saham perusahaan tersebut di pasar modal (Darmawan \& Astuti, 2016).

Berdasarkan tinjauan pustaka dan penelitian terdahulu yang sudah diuraikan diatas maka kerangka konseptual penelitian dapat digambarkan sebagai berikut:

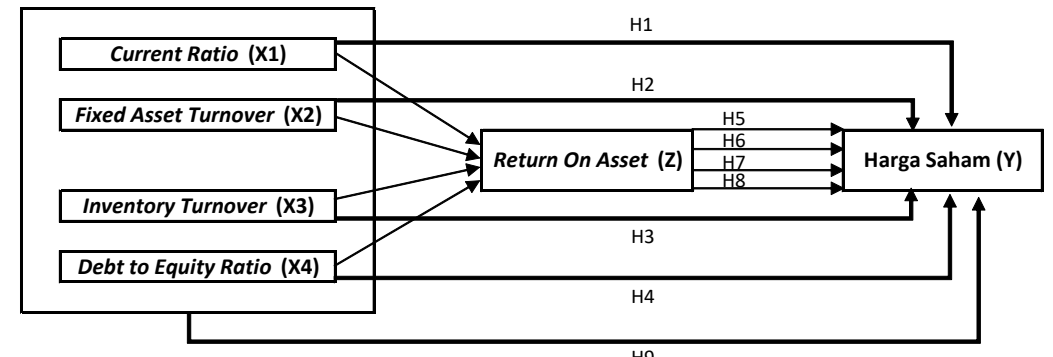

Gambar 1. Kerangka Konseptual

Sumber: Data Penelitian, 2019 
Menurut (Kasmir, 2012), current ratio (CR) merupakan rasio untuk mengukur kemampuan perusahaan dalam melunasi kewajiban jangka pendeknya. Angka CR yang tinggi menunjukkan risiko gagal bayar yang rendah. Sehingga investor akan tertarik untuk menanamkan modalnya pada perusahaan tersebut. Berdasarkan landasan teori tersebut maka dapat diajukan hipotesis sebagai berikut.

$\mathrm{H}_{1}$ : CR berpengaruh terhadap Harga Saham pada perusahaan consumer goods.

Menurut (Wild, John J., Subramanyam, K., R., \& Halsey, 2005) Inventory Turnover merupakan rasio yang mengukur kecepatan rata-rata pergerakan persediaan dalam perusahaan. ITO memberikan informasi kepada investor mengenai seberapa baik pengelolaan aset perusahaan. Berdasarkan landasan teori tersebut maka dapat diajukan hipotesis sebagai berikut.

$\mathrm{H}_{2}$ : ITO berpengaruh terhadap Harga Saham pada perusahaan consumer goods.

Menurut (Irham, 2012) debt to equity ratio (DER) digunakan untuk melihat seberapa tinggi modal perusahaan yang dibiayai oleh hutang, tingginya angka DER menunjukkan risiko gagal bayar perusahaan yang besar juga, hal tersebut akan menurunkan permintaan saham perusahaan tersebut di pasar modal. Berdasarkan landasan teori tersebut maka dapat diajukan hipotesis sebagai berikut.

$\mathrm{H}_{3}$ : DER berpengaruh terhadap Harga Saham pada perusahaan consumer goods.

Salah satu rasio aktivitas yang digunakan untuk mengukur efektivitas pemanfaatan aktiva tetap dalam menghasilkan penjualan adalah fixed asset turnover (FAT) (Aviliankara \& Sarumpaet, 2017). Semakin tinggi tingkat efisiensi perusahaan dalam memanfaatkan aset-asetnya maka akan semakin tinggi harga saham perusahaan (Lumbantobing, 2016). Berdasarkan landasan teori tersebut maka dapat diajukan hipotesis sebagai berikut.

$\mathrm{H}_{4}$ : FAT berpengaruh terhadap Harga Saham pada perusahaan consumer goods.

Rasio ROA yang semakin meningkat menunjukkan pemanfaatan aset yang baik oleh perusahaan dalam mendapatkan laba. Rasio likuiditas sendiri menunjukkan kemampuan perusahaan dalam memenuhi kewajiban jangka pendeknya sehingga rasio likuiditas juga dapat mencerminkan tingkat profitabilitas perusahaan. Hal tersebut dapat mempengaruhi permintaan dan penawaran saham perusahaan (Mardian, A. F., \& Sanusi, 2017). Berdasarkan landasan teori tersebut maka dapat diajukan hipotesis sebagai berikut.

$\mathrm{H}_{5}$ : CR berpengaruh terhadap Harga Saham pada perusahaan consumer goods dengan ROA sebagai variabel moderator.

Inventory Turnover (ITO) mencerminkan tingkat peningkatan persediaan perusahaan dikarenakan adanya kenaikan tingkat aktivitas. Semakin tingginya angka rasio ITO maka semakin tinggi pula tingkat profitabilitas perusahaan (AMANDA, 2019). Berdasarkan landasan teori diatas maka dapat diajukan hipotesis sebagai berikut.

$\mathrm{H}_{6}$ : ITO berpengaruh terhadap Harga Saham pada perusahaan consumer goods dengan ROA sebagai variabel moderator.

Debt to equity ratio (DER) menunjukkan besarnya hutang yang digunakan sebagai modal pada suatu perusahaan. Angka DER yang tinggi menunjukkan tingkat ketergantungan perusahaan yang tinggi pada hutang sehingga beban perusahaan akan bertambah dan hal tersebut akan mengurangi profitabilitas 
perusahaan. Hal ini akan mempengaruhi keputusan investor dalam membeli saham perusahaan tersebut (Dwisona \& Haryanto, 2015). Berdasarkan landasan teori tersebut maka dapat diajukan hipotesis sebagai berikut.

$\mathrm{H}_{7}$ : DER berpengaruh terhadap Harga Saham pada perusahaan consumer goods dengan ROA sebagai variabel moderator.

Fixed asset turnover (FAT) menunjukkan aktiva tetap yang digunakan oleh perusahaan dalam menghasilkan laba (Setyanto, 2018). Laba yang tinggi juga akan meningkatkan angka Return on asset (ROA) yang digunakan untuk mengukur efektivitas perusahaan. Investor sering mempertimbangkan efektivitas perusahaan sehingga hal tersebut dapat mempengaruhi harga saham (Wijayanti \& Hadiprajitno, 2019). Berdasarkan landasan teori diatas maka dapat diturunkan hipotesis penelitian sebagai berikut:

$\mathrm{H}_{8}$ : FAT berpengaruh terhadap Harga Saham pada perusahaan consumer goods dengan ROA sebagai variabel moderator.

Rasio finansial digunakan oleh perusahaan untuk memperkirakan tingkat keuntungan yang dapat diperoleh perusahaan di masa yang akan datang. Perubahan tingkat keuntungan perusahaan dapat mempengaruhi keputusan investasi (Pattiasina, 2018). Berdasarkan landasan teori daiatas maka dapat diturunkan hipotesis penelitian sebagai berikut.

$\mathrm{H}_{9}$ : CR, ITO, DER dan FAT berpengaruh secara simultan terhadap Harga Saham pada perusahaan consumer goods.

\section{METODE PENELITIAN}

Penelitian dilakukan terhadap perusahaan consumer goods yang tercatat di BEI. Pengambilan laporan keuangan dilakukan pada bulan Januari-Februari 2018. Adapun populasi yang digunakan berupa seluruh perusahaan dalam sektor consumer goods yang tercatat di BEI selama periode 2013-2017. Penelitian ini memakai teknik purposive sampling yang artinya pengambilan sampel dilakukan dengan teknik tertentu.Dimana sampel yang diambil merupakan laporan keuangan perusahaan sektor consumer goods yang terdaftar BEI. Kriteria yang digunakan untuk memilih sampel adalah sebagai berikut : Perusahaan terdaftar di BEI selama periode penelitian berlangsung yaitu selama periode 2013-2017, perusahaan yang mempublikasikan laporan keuangan selama periode penelitian yaitu dari tahun 2013-2017, perusahaan sektor consumer goods yang mencatat laba selama periode penelitian yaitu dari tahun 2013-2017, Perusahaan pada sektor consumer goods yang telah mempublikasikan harga saham dari 2013-2017 dan Laporan Keuangan perusahaan yang diterbitkan dalam bentuk mata uang rupiah. Populasi pada penelitian ini adalah sebanyak 39 perusahaan dan berdasarkan kriteria diatas maka sampel yang digunakan dalam penelitian ini adalah sebanyak 14 perusahaan.

Dalam penelitian ini, peneliti menggunakan software SPSS untuk melakukan metode analisis statistik. Untuk keperluan analisis data, peneliti terlebih dahulu melakukan uji asumsi klasik sebelum melakukan pengujian hipotesis. Pengujian hipotesis dilakukan dengan analisis regresi linear berganda. Model regresi yang dipakai adalah sebagai berikut:

$Y_{1}=\alpha+\beta_{1} X_{1}+\beta_{2} X_{2}+\beta_{3} X_{3}+\beta_{4} X_{4}+\varepsilon \ldots \ldots \ldots \ldots \ldots \ldots \ldots \ldots \ldots \ldots \ldots \ldots \ldots \ldots \ldots \ldots \ldots \ldots \ldots \ldots$
$Y_{2}=\alpha+\beta_{1} X_{1}+\beta_{2} X_{2}+\beta_{3} X_{3}+\beta_{4} X_{4}+\beta_{5} X_{1} Z+\beta_{6} X_{2} Z+\beta_{7} X_{3} Z+\beta_{8} X_{4} Z+\varepsilon$ 


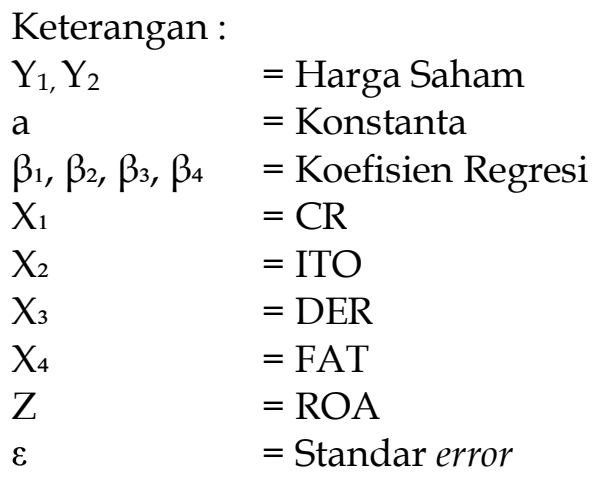

HASIL DAN PEMBAHASAN

Uji statistik lain yang dapat digunakan untuk menguji nomalitas residual adalah uji statistik non-parametrik Kolmogorov-Smirnov (K-S).

Tabel 1. Hasil Uji Normalitas Kolmogorov-Smirnov Test

\begin{tabular}{llr}
\hline & \multicolumn{2}{c}{$\begin{array}{c}\text { Unstandardized } \\
\text { Residual }\end{array}$} \\
\hline $\mathrm{N}$ & & 70 \\
Normal Parametersa & Mean & .0000000 \\
& Std. Deviation & 19377.20459 \\
Most Extreme Differences & Absolute & .157 \\
& Positive & .157 \\
& Negative & -.109 \\
Kolmogorov-Smirnov Z & & 1.317 \\
Asymp. Sig. (2-tailed) & & .062 \\
\hline
\end{tabular}

Sumber: Data Penelitian, 2019

Uji Normalitas dengan menggunakan kolmogorov-smirnov didapatkan nilai signifikan 0,062 > 0,05 yang berarti data berdistribusi normal dan dapat digunakan untuk melakukan uji lainnya karena memiliki nilai signifikansi > 0,05 (Ho diterima). Hasil uji multikolinieritas disajikan pada Tabel 2.

Tabel 2. Hasil Uji Multikolinieritas

\begin{tabular}{llc}
\hline Model & \multicolumn{2}{c}{ Collinearity Statistics } \\
\cline { 2 - 3 } & Tolerance & VIF \\
\hline 1 (Constant) & .796 & 1.256 \\
CR $($ X1) & .846 & 1.182 \\
FAT $($ X2) & .777 & 1.288 \\
ITO (X3) & .791 & 1.264 \\
DER (X4) &
\end{tabular}

Sumber: Data Penelitian, 2019

Hasil Uji Multikolinieritas menunjukkan bahwa nilai tolerance yang diperoleh untuk variabel $C R$ adalah sebesar 0,796, variable FAT sebesar 0,846, variabel ITO sebesar 0,777 dan variabel DER adalah sebesar 0,791. Nilai VIF CR adalah sebesar 1,256, variabel FAT sebesar 1,182, variabel ITO sebesar 1,288 dan variabel DER sebesar 1,264. Dari hasil tersebut dapat disimpulkan bahwa tidak terjadi multikolinieritas antar variabel independen dalam model regresi. Hasil uji autokorelasi disajikan pada Tabel 3. 
Tabel 3. Hasil Uji Autokorelasi

Unstandardized

Residual

\begin{tabular}{lr}
\hline Test Valuea & -5020.03064 \\
Cases $<$ Test Value & 35 \\
Cases $>=$ Test Value & 35 \\
Total Cases & 70 \\
Number of Runs & 31 \\
Z & -1.204 \\
Asymp. Sig. (2-tailed) & .229 \\
\hline
\end{tabular}

Sumber: Data Penelitian, 2019

Nilai signifikasi pada Run Test adalah 0,229>0,05 yang berarti data yang dipergunakan dalam penelitian ini cukup randomatau acak sehingga tidak terdapat masalah autokorelasi.

Hasil uji heteroskedastisitas dapat dilihat pada grafik scatterplot dimana titik-titik menyebar pada grafik sehingga dapat diambil kesimpulan bahwa pada data tidak terdapat masalah heteroskedastisitas.

\section{Scatterplot}

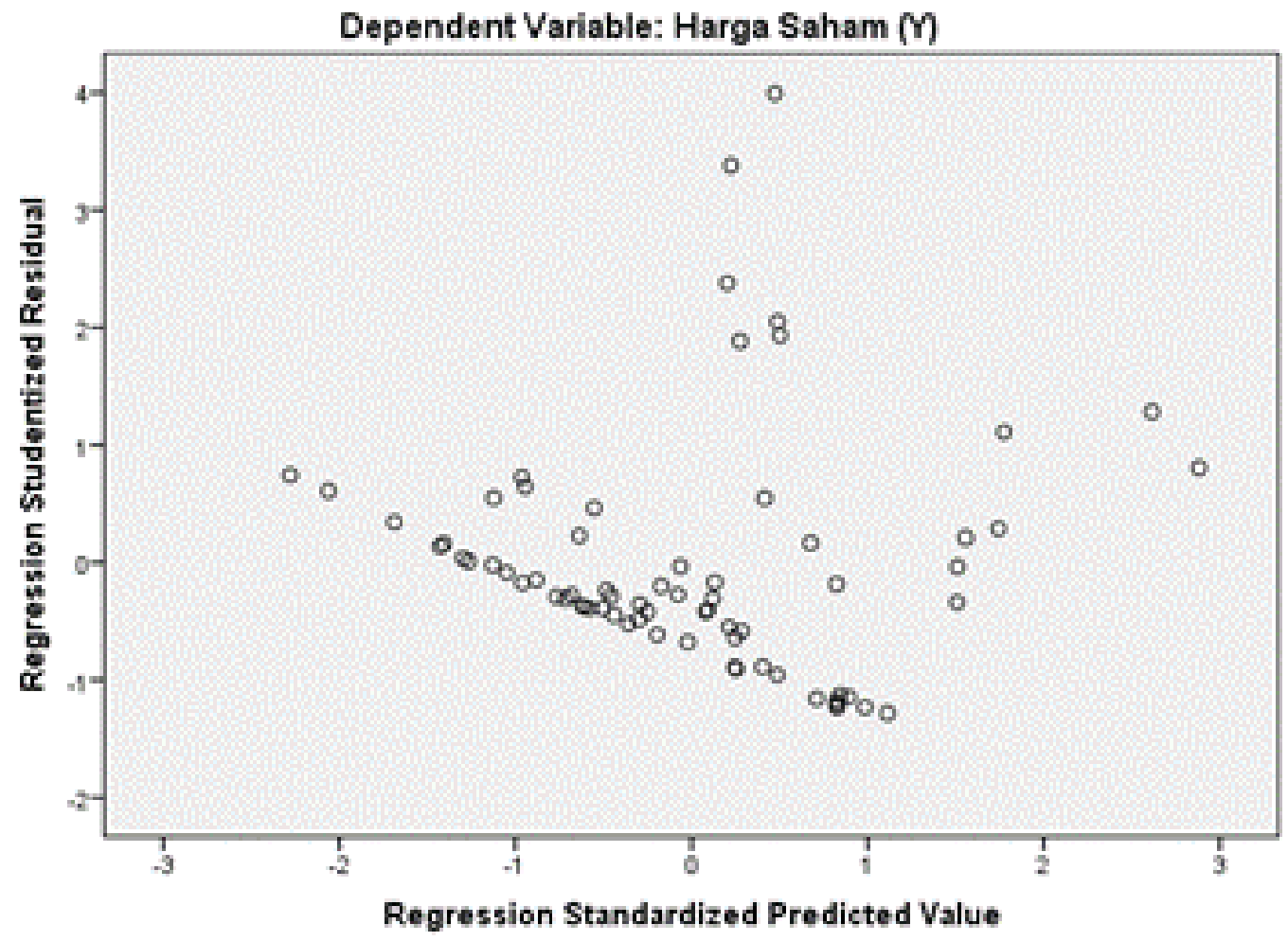

Sumber: Data Penelitian, 2019

Gambar 2. Analisis Grafik Scatterplot

Model penelitian yang dipakai dalam penelitian ini menggunakan metode analisis regresi linear berganda. Hasil analisis regresi linear berganda dapat dilihat pada Tabel 4 . 
Tabel 4. Hasil Regresi Linier Berganda

\begin{tabular}{|c|c|c|c|c|c|}
\hline \multirow[t]{2}{*}{ Model } & \multicolumn{2}{|c|}{ Unstandardized Coefficients } & \multirow{2}{*}{$\begin{array}{c}\begin{array}{l}\text { Standardized } \\
\text { Coefficients }\end{array} \\
\text { Beta }\end{array}$} & \multirow[t]{2}{*}{$\mathrm{T}$} & \multirow[t]{2}{*}{ Sig. } \\
\hline & $B$ & Std. Error & & & \\
\hline (Constant) & 8665.168 & 7817.573 & & 1.108 & 0.272 \\
\hline $\mathrm{CR}(\mathrm{X} 1)$ & -2694.170 & 1297.668 & -0.247 & -2.076 & 0.042 \\
\hline $\mathrm{FAT}(\mathrm{X} 2)$ & 2312.272 & 861.700 & 0.310 & 2.683 & 0.009 \\
\hline $\mathrm{ITO}(\mathrm{X} 3)$ & -476.372 & 247.155 & -0.232 & -1.927 & 0.058 \\
\hline $\operatorname{DER}(X 4)$ & 10420.718 & 4536.378 & 0.275 & 2.297 & 0.025 \\
\hline
\end{tabular}

Sumber: Data Penelitian, 2019

Dengan menggunakan variabel moderasi pada didapatkan hasil regresi linear berganda yang dapat dilihat pada Tabel 5 .

Tabel 5. Hasil Regresi Linier Berganda Variabel Moderasi

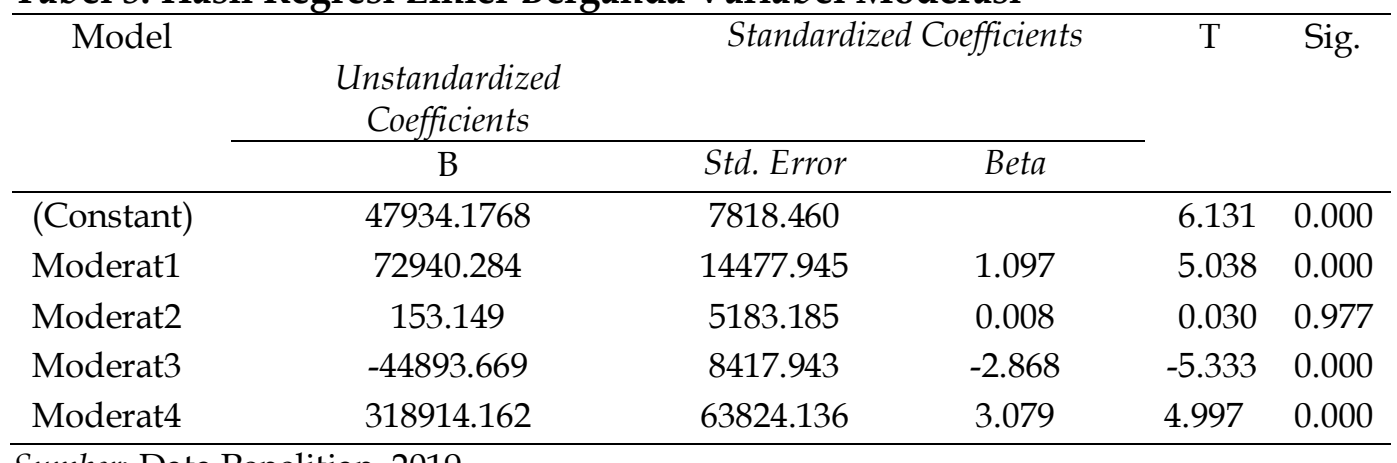

Sumber: Data Penelitian, 2019

Berdasarkan Tabel 4. dan Tabel 5. maka diperoleh persamaan linear berganda penelitian ini sebagai berikut :

Harga Saham $=8665,16-2694,17 \mathrm{CR}+2312,27 \mathrm{FAT}-476,37 \mathrm{ITO}+$ 10420,71DER. Harga Saham $=47934,1768+72940,284 C R . R O A+$ 153,149FAT.ROA - 44893,669ITO.ROA + 318914,162DER.ROA. Nilai koefisien $\mathrm{CR}\left(\mathrm{X}_{1}\right)$ adalah $-2694,17$. Ini menunjukkan bahwa setiap kenaikan CR sebesar satu persen, akan diiringi dengan penurunan Nilai Saham sebesar Rp.2.694,17. Dengan menggunakan ROA sebagai variabel moderator maka dapat dilihat terdapat perubahan pengaruh variabel CR terhadap Nilai Saham menjadi positif. Nilai koefisien FAT $\left(X_{2}\right)$ adalah 2,312. Ini menunjukkan bahwa setiap peningkatan FAT sebesar satu kali, maka Harga Saham juga mengalami peningkatan sebesar Rp.2.312,27. Nilai koefisien ITO $\left(X_{3}\right)$ adalah $-476,37$. Ini menunjukkan bahwa setiap kenaikan ITO sebesar satu persen akan membuat Harga Saham mengalami penurunan sebesar Rp.476,37. Nilai koefisien DER $\left(X_{4}\right)$ adalah 10420,71. Ini menunjukkan bahwa setiap peningkatan DER sebesar satu, akan meningkatkan Harga Saham sebesar Rp.10.420,71. Koefisien determinasi pada penelitian ini dilakukan sebanyak 2 (dua) kali dengan menggunakan variabel moderasi pada hasil kedua, adapun hasilnya dapat dilihat pada Tabel 6 . dan Tabel 7. 
Tabel 6. Hasil Koefisien Determinasi

\begin{tabular}{lccccc}
\hline Model & $R$ & $R$ Square & $\begin{array}{c}\text { Adjusted } R \\
\text { Square }\end{array}$ & $\begin{array}{c}\text { Std. Error of } \\
\text { The Estimate }\end{array}$ & $\begin{array}{c}\text { Durbin- } \\
\text { Watson }\end{array}$ \\
\hline 1 & \multicolumn{1}{l}{$0.516^{\mathrm{a}}$} & 0.266 & 0.221 & 19964.52546 & 1.744 \\
\hline a. & Predictors: (Constant), DER (X4), ITO (X3), FAT (X2), CR (X1) & \\
b. & Dependent Variable: Harga Saham (Y) \\
Sumber: & Data Penelitian, 2019 & & &
\end{tabular}

Berdasarkan Tabel 6. diperoleh nilai Adjusted R2 sebesar 0,221 atau 22,1 persen yang berarti perubahan variabel Harga Saham sebesar 22,1 persen dapat dijelaskan oleh variasi variabel CR, FAT, ITO dan DER, sedangkan sisanya sebesar 77,9 persen dapat dijelaskan oleh variabel-variabel selain variabel pada penelitian ini.

Tabel 7. Hasil Koefisien Determinasi Variabel Moderasi

\begin{tabular}{|c|c|c|c|c|c|}
\hline Mode & $\mathrm{R}$ & R Square & $\begin{array}{l}\text { Adjusted } R \\
\text { Square }\end{array}$ & $\begin{array}{l}\text { Std. Error of } \\
\text { The Estimate }\end{array}$ & $\begin{array}{l}\text { Durbin- } \\
\text { Watson }\end{array}$ \\
\hline 1 & $0.792^{a}$ & 0.627 & 0.578 & 14698.33068 & 1.944 \\
\hline $\begin{array}{l}\operatorname{Pr} \\
(X\end{array}$ & $\begin{array}{l}\text { redictors: (Constant), } \\
\text { र4), moderat2, moder }\end{array}$ & $\begin{array}{l}\text { moderat } 4, \text { ITC } \\
3\end{array}$ & & & \\
\hline & ependent Variable: & rga Saham $(Y$ & & & \\
\hline
\end{tabular}

Berdasarkan Tabel 7. dengan tambahan variabel moderasi ROA nilai Adjusted R2 menjadi 0,578 atau 57,8 persen yang berarti perubahan variabel Harga Saham sebesar 57,8persen dapat dijelaskan oleh variasi variabel CR, FAT , ITO, dan DER dengan ROA sebagai variabel moderasi, sedangkan sisanya 42,2 persen dapat dijelaskan oleh variabel diluar penelitian ini. Hal ini membuktikan bahwa variabel moderasi ROA meningkatkan kemampuan variabel bebas menjelaskan variable terikat dari 22,1 persen menjadi 57,8 persen

Hasil Uji F juga dilakukan sebanyak dua kali dimana hasil pengujian dapat diperhatikan pada Table 8 .

Tabel 8. Hasil Uji F Secara Simultan

\begin{tabular}{|c|c|c|c|c|c|}
\hline Model & $\begin{array}{l}\text { Sum of } \\
\text { Squares }\end{array}$ & $\mathrm{df}$ & Mean Square & $\mathrm{F}$ & Sig. \\
\hline \multicolumn{6}{|l|}{1.} \\
\hline Regression & 9.379E9 & 4 & 2.345E9 & 5.883 & $0.000 \mathrm{a}$ \\
\hline Residual & $2.591 \mathrm{E} 10$ & 65 & $3.986 \mathrm{E} 8$ & & \\
\hline Total & 3.529E10 & 69 & & & \\
\hline \multirow{2}{*}{\multicolumn{6}{|c|}{ Predictors: (Constant), DER (X4), FAT (X2), CR (X1), ITO (X2) }} \\
\hline & & & & & \\
\hline \multicolumn{6}{|c|}{ Sumber: Data Penelitian, 2019} \\
\hline \multicolumn{6}{|c|}{$\begin{array}{l}\text { Berdasarkan Tabel 8. dapat dilihat hasil Fhitung adalah } 5,883 \text {, dengan } \\
\text { menggunakan tabel } \mathrm{F} \text { maka diperoleh } \mathrm{df}_{1}=\mathrm{k}(5)-1=4 \mathrm{dan} \mathrm{df}_{2}=70-5=65 \text { dengan } \\
\text { nilai Ftabel adalah } 2,51 \text { maka diperoleh hasil Fhitung }>\text { Ftabel }(5,883>2,51) \text { maka } \\
\mathrm{H}_{0} \text { ditolak dan } \mathrm{H}_{\mathrm{a}} \text { diterima yang berarti secara simultan } \mathrm{CR} \text {, FAT, ITO dan } \\
\text { DERberpengaruh terhadap Nilai Saham perusahaan consumer goods yang } \\
\text { tercatat di BEI periode 2013-2017. }\end{array}$} \\
\hline
\end{tabular}


Tabel 9. Hasil Uji F Secara Simultan Variabel Moderasi

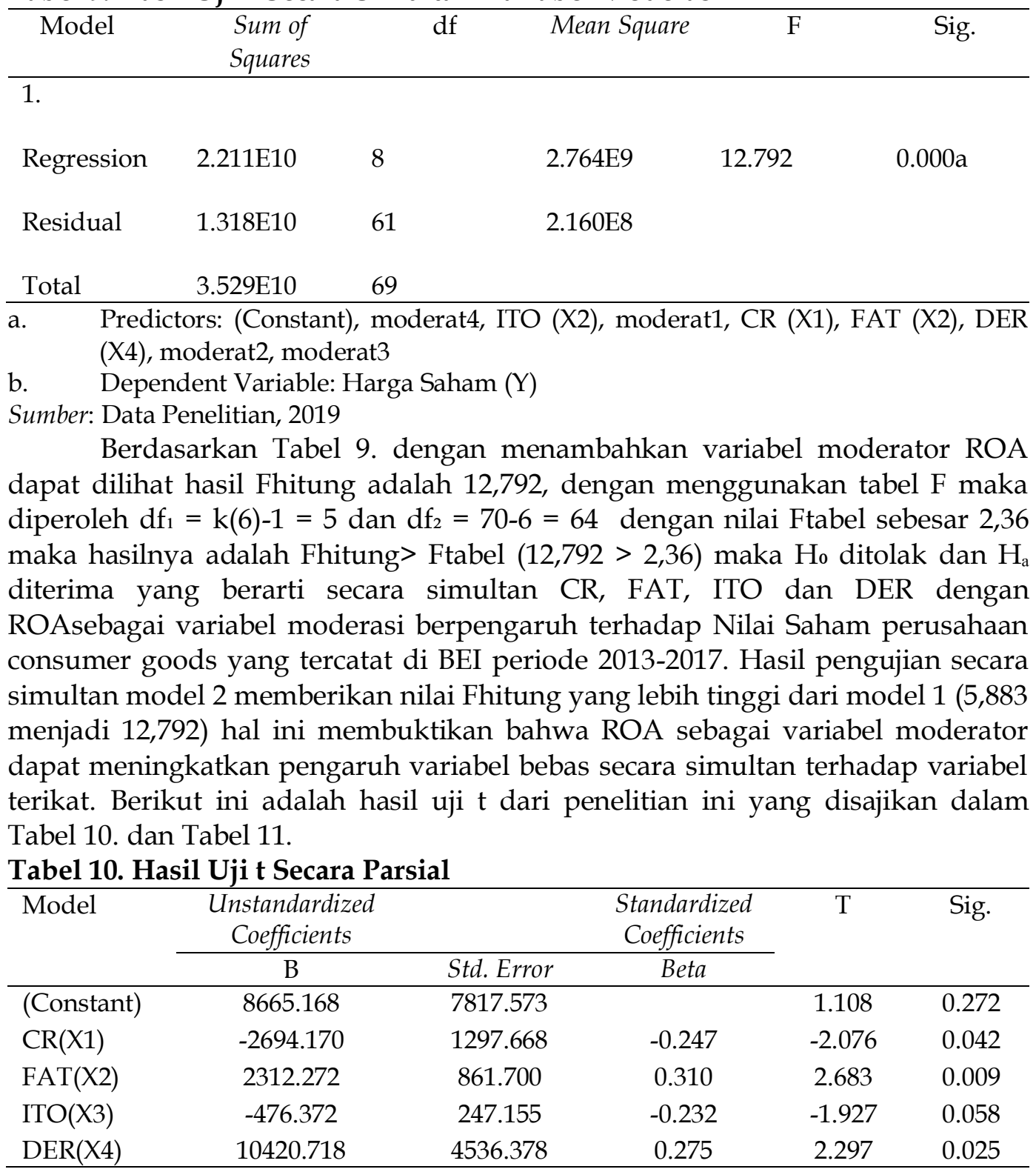

a. Dependent Variable: Harga Saham (Y)

Sumber: Data Penelitian, 2019

Pada Tabel 10. menunjukkan bahwa variabel CR mempunyai nilai tabel sebesar 1,9971 (Uji t = 70-5 = 65), maka ttabel<-thitung $(1,9971<-2,076)$ dengan tingkat signifikan 0,042 <0,05. Dari hasil uji t tersebut dapat dilihat bahwa hasil hipotesis penelitian Ho diterima dan Ha ditolak yang artinya secara parsial CR tidak memiliki pengaruh terhadap Nilai Saham pada perusahaan consumer goods. Penelitian ini memiliki hasil yang tidak sejalan dengan penelitian oleh (Elwisam, 2018) yang menyatakan bahwa Current Ratio memiliki pengaruh negatif signifikan terhadap Nilai Saham.

Variabel FAT mempunyai nilai tabel sebesar 1,9971, maka hasil thitung > ttabel $(2,683>1,9783)$ dengan nilai signifikan 0,009 > 0,05. Maka dari hasil uji tersebut dapat disimpulkan bahwa FAT memiliki pengaruh positif dan 
signifikan terhadap Harga Saham pada perusahaan consumer goods. Penelitian ini sejalan dengan hasil penelitian oleh (Aviliankara \& Sarumpaet, 2017) menyatakan bahwa FAT memiliki pengaruh positif terhadap harga saham. Dimana peningkatan angka FAT menunjukkan pemanfaatan aset tetap yang baik oleh perusahaan sehingga akan meningkatkan minat investor terhadap perusahaan tersebut.

Variabel ITO mempunyai nilai tabel sebesar 1,9971, maka hasil ttabel<thitung(1,9971>-1,927) dengan nilai signifikansi 0,058 > 0,05. Dari hasil tersebut dapat dilihat bahwa hipotesis penelitian Ha ditolak dan $\mathrm{H} 0$ diterima yang artinya secara parsial ITO tidak memiliki pengaruh terhadap Harga Saham perusahaan consumer goods yang tercatat di BEI periode 2013-2017. Penelitian ini memiliki hasil berbeda dengan hasil penelitian sebelumnya oleh (Satria, 2018) yang menyatakan bahwa ITO memiliki pengaruh positif dan signifikan terhadap Nilai Saham.

Variabel DER mempunyai nilai tabel sebesar 1,9971, maka hasil thitung > ttabel $(2,297>1,9783)$ dengan nilai signifikan $0,025<, 0,05$. Dari hasil uji $t$ tersebut dapat disimpulkan bahwa hasil hipotesis penelitian Ha diterima dan $\mathrm{H} 0$ ditolak yang artinya secara parsial DER memiliki pengaruh positif dan signifikan terhadap Nilai Saham pada perusahaan consumer goods yang tercatat di BEI periode 2013-2017. Hasil penelitian ini tidak sejalan dengan hasil penelitian terdahulu oleh (Wahyu Pranajaya \& Putra, 2018) yang menyatakan bahwa DER memiliki pengaruh negatif terhadap Harga Saham. Dimana angka DER yang tinggi menunjukkan angka hutang perusahaan yang tinggi sehingga akan mengurangi kepercayaan investor.

Tabel 11. Hasil Uji t Secara Parsial Variabel Moderasi

\begin{tabular}{|c|c|c|c|c|c|}
\hline \multirow[t]{2}{*}{ Model } & \multirow{2}{*}{$\begin{array}{l}\text { Unstandardized } \\
\text { Coefficients } \\
\text { B }\end{array}$} & \multicolumn{2}{|c|}{ Standardized Coefficients } & \multirow[t]{2}{*}{$\mathrm{T}$} & \multirow[t]{2}{*}{ Sig. } \\
\hline & & Std. Error & Beta & & \\
\hline (Constant) & 47934.768 & 7818.460 & & 6.131 & 0.000 \\
\hline $\mathrm{CR}(\mathrm{X} 1)$ & -5094.259 & 1211.521 & -0.468 & -4.205 & 0.000 \\
\hline $\mathrm{FAT}(\mathrm{X} 2)$ & -4196.450 & 1417.430 & -0.563 & -2.961 & 0.004 \\
\hline $\mathrm{ITO}(\mathrm{X} 3)$ & -113.972 & 238.016 & -0.056 & -0.479 & 0.634 \\
\hline $\operatorname{DER}(X 4)$ & -5507.791 & 6139.208 & -0.145 & -0.897 & 0.373 \\
\hline Moderat1 & 72940.284 & 14477.945 & 1.097 & 5.038 & 0.000 \\
\hline Moderat2 & 153.149 & 5183.185 & 0.008 & 0.030 & 0.977 \\
\hline Moderat3 & -44893.669 & 8417.943 & -2.868 & -5.333 & 0.000 \\
\hline Moderat4 & 318914.162 & 63824.136 & 3.079 & 4.997 & 0.000 \\
\hline
\end{tabular}

a. $\quad$ Dependent Variable: Harga Saham (Y)

Sumber: Data Penelitian, 2019

Tabel 11. menunjukkan hasil Uji $\mathrm{t}$ dengan menggunakan variabel moderasi ROA dan untuk variabel CR diperoleh nilai tabel sebesar 1,9977 (Uji t = $70-6=64)$, maka thitung $>$ ttabel $(5,038>1,9977)$ dengan tingkat signifikansi 0,00 $<0,05$. Hal ini menunjukkan bahwa hasil hipotesis penelitian $\mathrm{H}_{0}$ ditolak dan $\mathrm{H}_{\mathrm{a}}$ diterima yang artinya secara parsial CR memiliki pengaruh positif dan signifikan terhadap Nilai Saham dengan variabel moderasi ROA pada perusahaan consumer goods. Hal ini sejalan dengan penelitian oleh (Fitriah \& Sudirjo, 2016) yang menyatakan bahwa perusahaan dengan tingkat likuiditas yang baik akan 
memungkinkan pembayaran deviden yang lebih baik dan hal tersebut akan meningkatkan minat investor untuk menanamkan modalnya dan akan mengakibatkan peningkatan harga saham.

Dengan menggunakan variabel moderasi ROA maka FAT mempunyai nilai tabel sebesar 1,9977 (Uji $\mathrm{t}=70-6=64)$, maka thitung $<$ ttabel $(0,030<1,9977$ ) dengan tingkat signifikan 0,977>0,05. Hal ini menunjukkan H0 diterima bahwa secara parsial FAT tidak memiliki pengaruh terhadap Harga Saham dengan variabel moderasi ROA terhadap perusahaan consumer goods.

Dengan menggunakan variabel moderasi ROA, diperoleh nilai tabel sebesar 1,9977 (Uji $t=70-6=64)$, maka ttabel $>$-thitung $(1,9977>-5,333)$ dengan tingkat signifikansi $0,000<0,05$. Hal ini menyatakan bahwa hasil hipotesis penelitian $\mathrm{H}_{0}$ diterima dan $\mathrm{H}_{\mathrm{a}}$ ditolak yang artinya ITO tidak memiliki pengaruh terhadap harga saham dengan variabel ROA sebagai variabel moderasi pada perusahaan consumer goods. Penelitian ini memiliki hasil berbeda dengan hasil penelitian sebelumnya oleh (Mudlofir, Andini, \& Supriyanto, 2016) yang menyatakan bahwa ITO memiliki pengaruh positif terhadap harga saham.

Dengan menggunakan variabel moderasi ROA diperoleh hasil bahwa variabel DER mempunyai nilai tabel sebesar 1,9977 (Uji $t=70-6=64$ ), maka thitung $>$ ttabel $(4,997>1,9977)$ dengan tingkat signifikansi $0,000<0,05$. Hal ini menyatakan bahwa secara parsial DER memiliki pengaruh positif dan signifikan terhadap Harga Saham dengan ROA sebagai variabel moderasi dapat memperkuat pengaruh variabel DER terhadap Nilai Saham. Penelitian ini tidak sejalan dengan penelitian terdahulu oleh $(P, 2016)$ yang menyatakan bahwa DER memiliki pengaruh negatif dan signifikan terhadap Harga Saham. Dimana angka DER yang tinggi menunjukkan angka hutang perusahaan yang tinggi sehingga laba perusahaan cenderung digunakan untuk membayar hutang dibandingkan dengan pembagian dividen.

Hasil pengujian untuk model 1 menunjukkan variabel CR dan ITO tidak berpengaruh terhadap harga saham sedangkan untuk model 2 menunjukkan variabel FAT dan ITO tidak memiliki pengaruh terhadap nilai saham, tetapi perlu diperhatikan bahwa nilai thitung dengan ROA sebagai variabel moderasi menunjukkan nilai yang lebih tinggi dan nilai signifikansi yang lebih tinggi juga. ROA sebagai variabel moderasi telah mampu menguatkan pengaruh variabel bebas terhadap variabel terikat sehingga pelaksanaan dalam menilai kinerja keuangan sebuah perusahaan sangat penting melihat kondisi ROA yang terjadi. Tingginya angka ROA cenderung menunjukkan kemampuan perusahaan dalam menghasilkan laba yang lebih baik dan pemanfaatan aset yang baik oleh perusahaan (Manoppo, 2015).

Hasil pengujian untuk model 1 juga menunjukkan bahwa variabel FAT dan DER berpengaruh terhadap harga saham sedangkan untuk model 2 menunjukkan bahwa variabel CR dan DER berpengaruh terhadap harga saham. Nilai thitung yang lebih tinggi menunjukkan bahwa ROA sebagai variabel moderasi menguatkan pengaruh variabel bebas terhadap variabel terikat sehingga dapat disimpulkan bahwa kondisi ROA mempunyai pengaruh dalam penilaian kinerja keuangan suatu perusahaan. ROA merupakan ukuran efektivitas manajemen perusahaan dalam menghasilkan laba dengan menggunakan asetnya. Dengan kemampuan manajemen perusahaan yang baik 
maka investor akan tertarik untuk menanamkan modalnya pada perusahaan sehingga Nilai Saham perusahaan juga akan meningkat (Mogonta \& Pandowo, 2016).

\section{SIMPULAN}

Penelitian ini memiliki jumlah sampel yang masih terbatas pada 14 perusahaan consumer goods yang tergabung dalam Bursa Efek Indonesia sehingga disarankan kepada peneliti selanjutnya untuk mengambil sampel yang lebih banyak dengan menambahkan periode tahun penelitian dan juga menggunakan faktor-faktor lain yang mempengaruhi harga saham pada sektor berbeda guna mengetahui apakah hal yang sama juga berlaku pada sektor lainnya.

\section{REFERENSI}

Alaghi, K. (2013). Determinants Of Systematic Risk Of The Listed Companies In Tehran Stock Exchange. Journal Of Basic And Applied Scientific Research, 3(1), 596-600.

Amanda, R. I. (2019). The Impact Of Cash Turnover, Receivable Turnover, Inventory Turnover, Current Ratio And Debt To Equity Ratio On Profitability. Journal Of Research In Management, 2(2), 14-22. Https://Doi.Org/10.32424/Jorim.V2i2.66

Angelina, C., \& Lim, S. (2020). Pengaruh Current Ratio , Debt To Equity Ratio , Perputaran Kas Dan Total Asset Turnover ( TATO ) Terhadap Profitabilitas Pada Perusahaan Food \& Beverages Yang Terdaftar Di Bursa Efek Indonesia. 4.

Arab, R. O., Masoumi, S. S., \& Barati, A. (2015). Financial Performance Of The Steel Industry In India: A Critical Analysis. Middle-East Journal Of Scientific Research, 23(6), 1085-1090.

Arief, I. A. (N.D.). Kinerja 10 Emiten Konsumer Q1-2019, Siapa Terbaik \& Terburuk? Retrieved March 5, 2020, From Https://Www.Cnbcindonesia.Com/Market/20190503132010-1770345/Kinerja-10-Emiten-Konsumer-Q1-2019-Siapa-Terbaik-Terburuk

Arkan, T. (2016). The Importance Of Financial Ratios In Predicting Stock Price Trends: A Case Study In Emerging Markets. Zeszyty Naukowe Uniwersytetu Szczecińskiego Finanse Rynki Finansowe Ubezpieczenia, 1(1), 1326.

Aviliankara, D. M., \& Sarumpaet, T. L. (2017). Rasio Aktivitas , Dan Rasio Profitabilitas Terhadap Harga Saham ( Studi Empiris Pada Perusahaan Manufaktur Sektor Barang Konsumsi Yang Terdaftar Di Bursa Efek Indonesia Periode 2013-2015 ). 298-309.

Darmawan, R., \& Astuti, D. S. (2016). Pengaruh Return On Asset Dan Inventory Turnover Terhadap Harga Saham. Jurnal, 3(3), 109-114.

Dwisona, S. W., \& Haryanto, A. M. (2015). Analisis Pengaruh Faktor Fundamental Terhadap Harga Saham Dengan ROA Sebagai Variabel Intervening Pada Perusahaan LQ 45Periode 2010-2013. Diponegoro Journal Of Management, 4(3), 1-13. 
Elwisam, R. Y. A. (2018). Pengaruh Current Ratio, Return On Assets, Debt To Equity Ratio Dan Total Assets Turnover Terhadap Harga Saham Pada Perusahaan LQ45 Tahun 2013-2015. Jurnal Ilmu Manajemen, 14(2), 26-42.

Mardian, A. F., \& Sanusi, F. (2017). Pengaruh Likuiditas Terhadap Harga Saham Dengan Profitabilitas Sebagai Variabel Intervening Pada Perusahaan Manufaktur Sektor Aneka Industri Yang Terdaftar Di BEI Periode 20132016. Tirtayasa Ekonomika, 12(2), 196-211.

Fitriah, \& Sudirjo, F. (2016). Pengaruh Analisis Rasio Keuangan , Rasio Pasar Dan Kebijakan Deviden Terhadap Harga Saham. Jurnal Ilmiah UNTAG Semarang, 5(2), 1-16.

Ghozali, I. (2016). Aplikasi Analisis Multivariete Dengan Program IBM SPSS 23. Semarang: Badan Penerbit Universitas Diponegoro.

Gultom, M. L., Purba, D. P., Zepria, \& Sinaga, R. (2019). Pengaruh Current Ratio (Rasio Lancar), Return On Equity Dan Total Asset Turn Over (TATO) Terhadap Harga Saham Pada Sector Consumer Goods Industry Di Bursa Efek Indonesia. Jurnal Global Manajemen, 8(1), 35-44.

Hoiriya, \& Lestariningsih, M. (2015). Pengaruh Perputaran Modal Kerja, Perputaran Piutang, Perputaran Persediaan Terhdap Profitabilutas Perusahaan Manufaktur. Jurnal Ilmu Dan Riset Manajemen, 4(April), 1-15.

Hartono, J. (2015). Teori Portofolio Dan Analisis Investasi. BPFE.

Harmono. (2014). Manajemen Keuangan Berbasis Balanced Scorecard. Jakarta: PT. Bumi Aksara.

Hussain, S. I. (2017). An Empirical Analysis In Effect Of Macroeconomic Factors On Inflation For Pakistan. SSRN Electronic Journal, 29-30.

Hutapea, A. W., Saerang, I. S., \& Tulung, J. E. (2015). Pengaruh Debt To Assets Ratio, Debt To Equity Ratio, Return On Assets Dan Net Profit Margin Terhadap Harga Saham. Jurnal EMBA, 5(2), 16-36. Retrieved From Https:/ / Ejournal.Unsrat.Ac.Id/Index.Php/Emba/Article/View/15718

Irham, F. (2012). Analisa Kinerja Keuangan. Bandung: Alfabeta.

Jermsittiparsert, K., Ambarita, D. E., Mihardjo, L. W. W., \& Ghani, E. K. (2019). Risk-Return Through Financial Ratios As Determinants Of Stock Price: A Study From ASEAN Region. Journal Of Security And Sustainability Issues, 9(1), 199-210.

Kasmir. (2012). Analisis Laporan Keuangan. Jakarta: Rajawali Press.

Lumbantobing, R. (2016). Efek Rasio Likuiditas, Rasio Profitabilitas Dan Rasio Aktivitas Pada Harga Saham Yang Dimediasi Oleh Rasio Solvabilitas Perusahaan Sub-Sektor Perkebunan Yang Tercatat Di Bursa Efek Indonesia. Ilmiah Manajemen Bisnis, 16(2).

Manoppo, C. P. (2015). The Influence Of Roa, Roe, Ros, And Eps On Stock Price. Jurnal Riset Ekonomi, Manajemen, Bisnis Dan Akuntansi, 3(4), 691-697.

Mardian, A. F., \& Sanusi, F. (2017). Pengaruh Likuiditas Terhadap Harga Saham Dengan Profitabilitas Sebagai Variabel Intervening Pada Perusahaan Manufaktur Sektor Aneka Industri Yang Terdaftar Di BEI Periode 20132016. Tirtayasa Ekonomika, 12(2), 196-211.

Mogonta, K., \& Pandowo, M. (2016). Analyzing The Effect Of Return On Assets, Return On Equity And Earnings Per Share On Market Share Price: A 
Study Of Lq-45 Mining Companies Listed On Indonesia Stock Exchange. Jurnal Riset Ekonomi, Manajemen, Bisnis Dan Akuntansi, 4(2), 703-713.

Mohamad, S. J. A. N. Bin S., Suraidi, N. N., Rahman, N. A. A., \& Suhaimi, R. D. S. R. (2016). A Study On Relationship Between Inventory Management And Company Performance: A Case Study Of Textile Chain Store. Journal Of Advanced Management Science, 4(4), 299-304.

Mudlofir, Andini, R., \& Supriyanto, A. (2016). Pengaruh ROA, ROE, EPS, Inflasi ,DER Dan Inventory Turnover Terhadap Harga Saham Pada Perusahaan Otomotif Yang Terdaftar Di BEI Periode 2008-2013. Jurnal Of Accounting, 2(2).

Murhadi, W. R. (2013). Analisis Laporan Keuangan Proyeksi Dan Valuasi Saham. Jakarta: Salemba Empat.

P, S. M. E. (2016). Analisis Pengaruh Faktor Fundamental Terhadap Harga Saham Dengan ROA Sebagai Variabel Intervening Pada Saham Sektor Pertambangan Di Bursa Efek Indonesia Periode 2013-2015. 484-493.

Pattiasina, V. (2018). The Impact Of Financial Ratios Towards Profit Changes. International Research Journal Of Management, IT And Social Sciences, 5(5).

Priliyastuti, N., \& Stella, S. (2017). Pengaruh Current Ratio, Debt To Asset, Debt

To Equity, Return On Assets Dan Price Earnings Ratio Terhadap Harga

Saham. Jurnal Bisnis Dan Akuntansi, 19(5), 320-324.

Purnamawati, I. G. A. (2016). The Effect Of Capital Structure And Profitability On Stock Price (Study Of The Manufacturing Sector In Indonesia Stock Exchange). International Journal Of Business, Economics And Law, 9(1), 1016.

Rahmawati, D., \& Suryono, B. (2017). Pengaruh DPR , EPS Dan DER Terhadap Harga Saham. Jurnal Ilmu Dan Riset Akuntansi Volume, 6(6), 1-17.

Satria, R. (2018). Pengaruh Perputaran Piutang, Perputaran Persediaan, Dan Rasio Lancar Terhadap Profitabilitas Perusahaan Manufaktur Sektor Industri Barang Konsumsi Yang Terdaftar Di Bursa Efek Indonesia Periode 2013-2015. Sekuritas, 2(1), 138-146.

Setyanto, E. (2018). Pengaruh Perputaran Aktiva Tetap Dan Perputaran Piutang Terhadap Profitabilitas. Ekonomi Akuntan, 9(April), 51-69.

Siahaan, D. B. (2017). Pengaruh Pbv, Der Dan Roe Terhadap Harga Saham Perusahaan Manufaktur Yang Terdaftar Di Bursa Efek Indonesia. 5(3), 770-780.

Sugiyono. (2012). Manajemen Keuangan Teori, Konsep Dan Aplikasi. Ekonisia.

Sukamulja, S. (2017). Pengantar Pemodelan Keuangan Dan Analisis Pasar Modal. Yogyakarta: ANDI.

Suryahadi, A. (N.D.). Optimisme Konsumen Turun, Bagaimana Prospek Emiten Sektor Consumers Goods? Retrieved March 5, 2020, From Https:/ / Investasi.Kontan.Co.Id/News/Optimisme-Konsumen-TurunBagaimana-Prospek-Emiten-Sektor-Consumers-Goods?Page $=1$

Utami, W. B. (2017). Analysis Of Current Ratio Changes Effect, Asset Ratio Debt, Total Asset Turnover, Return On Asset, And Price Earning Ratio In Predictinggrowth Income By Considering Corporate Size In The Company Joined In LQ45 Index Year 2013 -2016. International Journal Of Economics, Business And Accounting Research (IJEBAR), 1(01). 
Wahyu Pranajaya, K., \& Putra, I. N. W. A. (2018). Pengaruh Earning Per Share, Debt To Equity Ratio, Dan Current Ratio Pada Harga Saham. E-Jurnal Akuntansi, 25, 1744.

Warrad, L., \& Al Omari, R. (2015). The Impact Of Activity Ratios Among Industrial Sectors' Performance: Jordanian Case. Research Journal Of Finance And Accountingonline), 6(6), 2222-2847.

Wijayanti, W., \& Hadiprajitno, B. (2019). Pengaruh Rasio Keuangan Terhadap Harga Saham Perusahaan Unggulan (Studi Empiris Pada Perusahaan Yang Konsisten Masuk Dalam Indeks LQ45 Tahun 2015-2017). Diponegoro Journal Of Accounting, 8(4), 1-10.

Wild, John J., Subramanyam, K., R., \& Halsey, R. R. (2005). Financial.

Wira, D. (2015). Analisis Fundamental Saham. Jakarta: Exceed. 